\title{
Predictors of Learning Autonomy and its Components
}

\author{
Anna Studenska \\ University of Silesia, Poland
}

\begin{abstract}
The aim of the research was to answer the following question: to what extent is the level of learning autonomy and its components related to personality traits and to what extent to parenting styles? One hundred and twenty four Polish students took part in the study. Neuroticism, extraversion, openness to experience, agreeableness, conscientiousness as well as exposition to democratic, authoritarian, permissive, and disengaged parenting styles were regarded as independent variables. The level of dependent variables - general learning autonomy and its components: self-control, reflexivity, independence of planning, openness to change, and caring for results was measured by Learning Autonomy Inventory (LAI), constructed for the purpose of the research. The results showed that the model including conscientiousness, openness to experience and exposition to democratic parenting style allowed for the best prediction of general learning autonomy. It was also found that personality traits are stronger predictors of general learning autonomy and its components than parental influences.
\end{abstract}

\section{Introduction}

The ability to "take charge of one's own life" is termed individual autonomy [1]. It has been proved that autonomy contributes to academic as well as professional achievements [2] [3] [4] and is related to the sense of well-being [5].

Research have shown that becoming autonomous person is a natural developmental process [6] which is related to personality traits and educational influences. Autonomy is conceptualized in various ways and there is a scarcity of unambiguous data concerning the relationship between personality traits, influences characteristic to parenting styles and autonomy [3][7]. Therefore the aim of the study was to collect empirical evidence concerning the extent to which learning autonomy and its components is related to personality traits and parental influences. The article is the extension of the text published in Ireland International Conference on Education Proceedings [8].

\section{Research background}

It was assumed that autonomy is a dependent variable related to personality traits and parenting styles.

\subsection{The notion of autonomy}

H. Murray claimed that autonomous individuals are characterised by independence and resistance to coercion as well as external influences and values [9]. Modern philosophers stress such criteria of personal autonomy as: having control over oneself and one's own life, reflecting critically upon one's desires, values, wishes and plans as well as ability to act in accordance with the results of such reflection [1] [10] [11]. L. Haworth [1] suggests that there are three components of autonomy: competence combined with innovativeness and creativity, independence from others, and control over one's emotions and desires. R. Ryan and E. Deci defined autonomy as the capacity to govern one's own life. According to self-determination theory an action is highly autonomous if it is consistent with the value and goal system of the person who is performing it, and is experienced as satisfying and rewarding [5].

Learning autonomy is defined as "responsibility for, one's learning" and encompasses independent control over leaning content, affective processes and study strategies [12]. Learning can be called autonomous if it is a result of person's own intention [13]. A set of behaviours which are directed towards achieving learning goal is termed self regulated learning. These behaviors are connected with planning, realization and monitoring of learning process as well as with reflecting on it's result [14].

\subsection{The relationship between personality traits and autonomy}

Research results concerning the relationship between autonomy and personality traits depend on the way in which autonomy is conceptualized. R. Koestner and G. Losier [9] by means of regression analysis showed that autonomy, understood as a tendency to separate from other people, measured by Adjective Check List created by H. Gough and A. Heilbrun was related negatively to agreeableness and positively to extraversion and openness to experience. B. Hmel and A. Pincus [3] analysed 15 various research tools and grouped them according to operational definitions of autonomy which were used 
in their construction. The Authors proved that autonomy conceptualized as the tendency to separate oneself from other people correlated negatively with extraversion and agreeableness. The measurements of autonomy defined as self-governance were related negatively to neuroticism and positively to extraversion, openness, agreeableness and conscientiousness.

It was shown that information contained in genes may account for up to half of the variance in personality traits from Five Factor Model [15]. The presented picture of relationships shows that autonomy correlates with personality traits which are heritable. This means, that autonomy itself may be under significant influence of genetic factor.

\subsection{Parenting styles}

Actions intended to support autonomy belong to a wider group of means and methods which parents and other family members use to rear their children, termed parenting styles. These styles are classified and described according to basic dimensions of parent- child relationship. There is an agreement that there are three such dimensions [16] [17] [18] [19] .

- responsiveness (nurture or warmth - rejection) the level in which parents respond to children's needs and express their love;

- demandingness (authority, or structure - chaos) the extent to which parents provide their children with rules of behavior and supervise compliance to them;

- autonomy support (coercion, encouragement) belief in child's abilities to succeed in life tasks.

Parenting styles are classified and termed according to the place of parental influences on above-mentioned dimensions. The wildly known and used classification comes from D. Baumrind [16] [17] and distinguishes three parenting styles:

- Authoritarian - which combines high demandingness and low responsiveness;

- Authoritative - characterized by high level of demandingness and responsiveness;

- Permissive - combining low demandingness and high responsiveness;

In more detailed classifications (Baumrind 2005)

other styles are distinguished, such, as:

- Democratic with high responsiveness but moderate demandingness;

- Rejecting and neglecting styles, which are characterized by low responsiveness and low demandingness. These are combined with hostility in the case of rejecting style, and indifference in the case of neglecting style.

\subsection{Research results concerning parenting styles and autonomy}

Among parenting styles the authoritative one is regarded as the most beneficial to autonomy development [19]. D. Baumrind [17] states, that this is due to the fact, that authoritative parental influences combine high warmth, autonomy support and control over child behaviour with minimal psychological control. According to this Author [16] it is consistency of parents' loving relationship with a child and not asserting power, which is critical to developing child's ability to make independent and conscious decisions.

Researchers found various beneficial effects of authoritative parenting style. L. Steinberg, J. Elmen, and N. Mounts [20] showed that authoritative parental influences result in increased autonomy, psychosocial maturity and healthy work orientation, which in turn leads to academic success. Longitudinal research conducted in 1991 by $\mathrm{D}$. Baumrind [21] proved that authoritative parenting style is connected with increased intrinsic motivation, self control and ability to take other's point of view. B. Soenens and M. Vansteenkiste [7] proved that maternal and paternal autonomy support was significantly and positively related to performing academic duties and engaging in friendships out of identified and intrinsic motivation. Autonomy support by parents was shown to affect beneficially self-regulatory capacities in children [22] [23].

\section{Problem and hypotheses}

Because of various ways in which autonomy is conceptualized there is scarcity of unambiguous data presenting relationship between personality traits, influences characteristic to various parenting styles and autonomy. Moreover, given that autonomy is a complex construct there seems to be a need to gather evidence concerning whether all learning autonomy components or only some of them are related to personality traits and parenting styles. Therefore, the main problem of the research was formulated as follows: to what extent is the level of learning autonomy and its components related to personality traits and to what extent to influences characteristic to parenting styles?

The main research problem was then transformed into four following research questions:

1. Which of personality traits and kinds of exposition to parenting styles selected for the research should be included in the model which allows for the best prediction of general learning autonomy?

2. How much of general learning autonomy variance can be explained by personality traits 
and kinds of exposition to parenting styles included in the model which allows for the best prediction of general learning autonomy?

3. Which group of variables: personality traits or parental influences are better predictors of general learning autonomy?

4. Which personality traits and kinds of exposition to parenting styles should be included in best predictive models of learning autonomy components?

\section{Method}

\subsection{Participants}

The research was conducted among pedagogy students. Data was gathered from 124 persons, including 115 women and 9 men. The average age of participants was 20,7 years $(\mathrm{SD}=1,21)$.

\subsection{Instruments}

Five personality dimensions: neuroticism, extraversion, openness, agreeableness and conscientiousness were measured using Polish version of Costa and McCrae`s NEO-FFI Inventory [24].

Information concerning parenting styles was gathered with "Parenting styles in a family" questionnaire constructed by M. Ryś [25]. The instrument consists of 34 statements. Each statement is rated on a 5-point scale ranging from "definitely no" (0 points) to "definitely yes" (4 points). The raw result for each participant consists of four sums reflecting exposition to influences characteristic to the following four parenting styles:

- Democratic $(\alpha=0,90)$, eg.: "My parents showed respect to the rights and feelings of each family member",

- Authoritarian $(\alpha=0,90)$, eg.: "In my family the parents 'opinion was the only one that mattered",

- Permissive $(\alpha=0,54)$, eg.: "The atmosphere in my home, thanks to my parents was characterized by love, gentleness and not imposing demands which would stress me",

- Disengaged $(\alpha=0,87)$, eg.: "My parents were busy with their own affairs, when I was a child I had to satisfy my needs myself".

Learning autonomy was measured by Learning Autonomy Inventory [26]. According to the conceptions of L. Haworth [1] and B. Zimmerman [14] for the purpose of the Inventory construction, learning autonomy was defined as competence, independence from other people and one's own emotions and desires in planning, realization and evaluation of one's own learning.

Psychometric characteristics of the Inventory was described on the basis of data obtained from 285 participants (university students and lower secondary school students). Principal components analysis and varimax rotation with Kaiser normalization allowed for extraction of five components $(45,6 \%$ of variance explained) and to divide 33 inventory statements into following scales:

- Self control (9 items, $\alpha=0,80$ ), eg.: "I devote certain time during the day to independent learning, even if nobody forces me to do it";

- Reflexivity (6 items, $\alpha=0,74$ ),eg.: "I evaluate whether what I'm planning to do is worth doing without waiting for other people's opinions or suggestions";

- Independence of planning ( 6 items, $\alpha=0,69$ ), eg.: "I plan what I will learn without other people's suggestions or prompting";

- Openness to change ( 5 items; $\alpha=0,72$ ), eg.: "I don't regard thinking whether I should change something in my learning a waste of time";

- Caring for results ( 7 items, $\alpha=0,71$ ), eg.: "I can choose learning methods which give the desired effects".

Each Inventory statement is rated on a 5-point scale ranging from "definitely no" ( 0 points) to "definintely yes" (4 points). It was found that there is a positive relationship between the general result of Learning Autonomy Inventory and conscientiousness measured by NEO-FFI, internal learning motivation and school grades [26].

\subsection{Statistical analysis}

According to the requirements of regression analysis procedure, variables were selected which correlate significantly with general learning autonomy and its components and do not correlate strongly with each other. Than, for each of dependent variables: general learning autonomy and its five components all possible standard regression models including selected variables were compared in terms of the values of Mallow`s Cp statistics [27]. Finally, models which allow for the best prediction of general learning autonomy and its components were chosen. Hierarchical multiple regression analysis was used to compare general learning autonomy variance which can be explained by the personality traits and exposition to parenting styles included in the best selected model. Analyses were conducted by means of Statistica 10.0 and SPSS 19.0 software. 


\section{Results}

\subsection{The relationship between personality traits, exposition to parenting styles and learning autonomy and its components}

Basic descriptive statistics and values of correlation coefficients between personality traits, exposition to parenting styles and general learning autonomy are presented in Table 1. Continuation of these statistics is shown in Table 2, containing data concerning the relationship between personality traits, parental influences and learning autonomy components. As can be seen from the values of Kolmogorov - Smirnov test, personality traits, exposition to democratic parenting style, general learning autonomy and all its components with the exception of openness to change proved to have normal distributions. The distributions of exposition to authoritarian, permissive, and disengaged parenting styles significantly deviated from normal one.

Table 1. Relationship between personality traits, parenting styles and general learning autonomy

\begin{tabular}{|c|c|c|c|c|c|c|c|c|c|c|}
\hline \multirow[b]{2}{*}{$\begin{array}{l}\text { Stati } \\
\text { stics }\end{array}$} & \multirow[b]{2}{*}{$\begin{array}{l}\text { Learning } \\
\text { autonomy } \\
\text { (Lau) }\end{array}$} & \multicolumn{5}{|c|}{ Personality traits } & \multicolumn{4}{|c|}{ Exposition to parenting styles } \\
\hline & & $\begin{array}{l}\text { Neuro } \\
\text { ticism } \\
\text { (Neu) }\end{array}$ & $\begin{array}{c}\text { Extra } \\
\text { version } \\
\text { (Ext) }\end{array}$ & $\begin{array}{l}\text { Openness } \\
\text { to expe } \\
\text { rience Ope) }\end{array}$ & $\begin{array}{c}\text { Agree } \\
\text { ableness } \\
\text { (Agr) }\end{array}$ & $\begin{array}{c}\text { Conscien } \\
\text { tiousness } \\
\text { (Con) }\end{array}$ & $\begin{array}{l}\text { Demo } \\
\text { cratic } \\
\text { (Dem) }\end{array}$ & $\begin{array}{c}\text { Authori } \\
\text { tarian } \\
\text { (Aut) }\end{array}$ & $\begin{array}{l}\text { Permissive } \\
\quad \text { (Per) }\end{array}$ & $\begin{array}{c}\text { Disen } \\
\text { gaged } \\
\text { (Dis) }\end{array}$ \\
\hline Mean & 88,85 & 23,19 & 30,94 & 26,89 & 30,87 & 32,02 & 30,99 & 9,6 & 24,31 & 6,47 \\
\hline SD & 11,96 & 8,13 & 6,02 & 5,87 & 5,46 & 5,81 & 6,12 & 7,21 & 3,82 & 5,8 \\
\hline $\begin{array}{l}\text { Skew } \\
\text { ness }\end{array}$ & $-0,67$ & 0,20 & $-0,11$ & $-0,17$ & $-0,49$ & $-0,15$ & $-0,76$ & 0,97 & $-0,43$ & 1,21 \\
\hline $\begin{array}{l}\text { Kurto } \\
\text { sis }\end{array}$ & 0,98 & 0,05 & 0,76 & 0,21 & $-0,03$ & 0,12 & 0,21 & 0,39 & $-0,13$ & 1,57 \\
\hline KS p & $p>0,20$ & $p>0,20$ & $p>0,20$ & $p>0,20$ & $p>0,10$ & $p>0,20$ & $p<0,15$ & $p<0,01$ & $p<0,05$ & $p<0,01$ \\
\hline Lau & $x$ & & & & & & & & & \\
\hline $\mathrm{Neu}$ & $r=-0,32^{\star *}$ & $\mathrm{x}$ & & & & & & & & \\
\hline Ext & $r=0,21^{*}$ & $r=-0,58^{* \star}$ & $\mathrm{x}$ & & & & & & & \\
\hline Ope & $r=0,24^{\star *}$ & $r=-0,36^{\star \star}$ & $r=0,34^{* \star}$ & $\mathrm{x}$ & & & & & & \\
\hline Agr & $r=0,18^{*}$ & $r=-0,34^{* \star}$ & $r=0,34^{\star \star}$ & $r=0,11$ & $\mathrm{x}$ & & & & & \\
\hline Con & $r=0,56^{* *}$ & $r=-0,26^{* *}$ & $r=0,175$ & $r=0,02$ & $r=0,26^{* *}$ & $x$ & & & & \\
\hline Dem & $\rho=0,39^{* *}$ & $\rho=-0,17^{*}$ & $\rho=0,17^{*}$ & $\rho=0,12$ & $\rho=0,24^{\star \star}$ & $\rho=0,32^{* *}$ & $\mathrm{x}$ & & & \\
\hline Aut & $\rho=-0,33^{\star *}$ & $\rho=0,23^{\star *}$ & $\rho=-0,16$ & $\rho=-0,08$ & $\rho=-0,27^{\star \star}$ & $\rho=-0,35^{\star \star}$ & $\rho=-0,77^{\star *}$ & $\mathrm{x}$ & & \\
\hline Per & $\rho=0,32^{\star *}$ & $\rho=-0,11$ & $\rho=0,08$ & $\rho=0,07$ & $\rho=0,20^{*}$ & $\rho=0,22^{\star *}$ & $\rho=0,81^{* *}$ & $\rho=-0,63^{* *}$ & $x$ & \\
\hline Dis & $\rho=-0,38^{* *}$ & $\rho=0,21^{*}$ & $\rho=-0,19^{*}$ & $\rho=-0,10$ & $\rho=-0,26^{\star *}$ & $\rho=-0,40^{\star \star}$ & $\rho=-0,80^{* \star}$ & $\rho=0,81^{\star *}$ & $\rho=-0,60^{* *}$ & $x$ \\
\hline
\end{tabular}

$\mathrm{N}=124$; KS p - significance of Kolmogorov - Smirnov normality test; r- Pearson correlation coefficient; $\rho$ - Spearman`s rank order correlation coefficient; $* \mathrm{p}<0,05 ; * * \mathrm{p}<0,01$

Table 2. Relationship between personality traits, parenting styles and learning autonomy components

\begin{tabular}{|c|c|c|c|c|c|}
\hline \multirow[b]{2}{*}{ Statistics } & \multicolumn{5}{|c|}{ Learning autonomy components } \\
\hline & $\begin{array}{l}\text { Self-control } \\
\text { (SCo) }\end{array}$ & Reflexivity (Ref) & $\begin{array}{l}\text { Independence } \\
\text { of planning } \\
\text { (IPI) }\end{array}$ & $\begin{array}{l}\text { Openness to change } \\
\text { (OCh) }\end{array}$ & $\begin{array}{l}\text { Care for the } \\
\text { results } \\
\text { (Cre) }\end{array}$ \\
\hline Mean & 23,06 & 17,79 & 17,28 & 12,23 & 18,50 \\
\hline SD & 4,78 & 2,69 & 2,91 & 2,40 & 3,15 \\
\hline Skewness & $-0,83$ & $-0,10$ & $-0,32$ & $-0,72$ & $-0,55$ \\
\hline Kurtosis & 1,27 & 0,25 & 0,93 & 0,47 & 0,46 \\
\hline KS p & $p>0,20$ & $p<0,10$ & $p<0,15$ & $p<0,05^{*}$ & $p<0,10$ \\
\hline Self-control (Sco) & $\mathrm{x}$ & & & & \\
\hline Reflexivity (Ref) & $r=0,31^{\star *}$ & $\mathrm{x}$ & & & \\
\hline Independence of planning (IPI) & $r=0,53^{\star *}$ & $r=0,41^{\star *}$ & $\mathrm{x}$ & & \\
\hline Openness to change (Och) & $r=0,41^{* *}$ & $r=0,25^{\star \star}$ & $r=0,39^{\star *}$ & $\mathrm{x}$ & \\
\hline Care for the results (Cre ) & $r=0,53^{* \star}$ & $r=0,48^{\star \star}$ & $r=0,57^{\star *}$ & $r=0,42^{\star \star}$ & $\mathrm{x}$ \\
\hline Learning autonomy (Lau) & $r=0,82^{* *}$ & $r=0,63^{\star *}$ & $r=0,78^{\star \star}$ & $r=0,63^{\star \star}$ & $r=0,81^{* *}$ \\
\hline Neuroticism (Neu) & $r=-0,09$ & $r=-0,28^{* *}$ & $r=-0,26^{* *}$ & $r=-0,08$ & $r=-0,54^{\star *}$ \\
\hline Extraversion (Ext) & $r=-0,01$ & $r=0,35^{\star \star}$ & $r=0,09$ & $r=0,00$ & $r=0,42^{\star *}$ \\
\hline Openness to experience (Ope ) & $r=0,06$ & $r=0,27^{\star \star}$ & $r=0,13$ & $r=0,11$ & $r=0,37^{* \star}$ \\
\hline Agreeableness (Agr) & $\mathrm{r}=0,10$ & $r=0,18^{*}$ & $r=0,05$ & $r=0,18^{*}$ & $r=0,20^{*}$ \\
\hline Conscientiousness (Con) & $r=0,59^{\star \star}$ & $r=0,24^{\star \star}$ & $r=0,33^{\star \star}$ & $r=0,36^{\star *}$ & $r=0,45^{\star *}$ \\
\hline Exposition to democratic parenting style (Dem) & $\rho=0,34^{\star \star}$ & $\rho=0,21^{*}$ & $\rho=0,23^{*}$ & $\rho=0,31^{* *}$ & $\rho=0,33^{\star *}$ \\
\hline Exposition to autocratic parenting style (Aut) & $\rho=-0,29^{\star *}$ & $\rho=-0,17^{*}$ & $\rho=-0,25^{\star}$ & $\rho=-0,25^{\star *}$ & $\rho=-0,27^{\text {** }}$ \\
\hline Exposition to permissive parenting style (Per) & $\rho=0,34^{\star *}$ & $\rho=0,18^{*}$ & $\rho=0,19^{*}$ & $\rho=0,24^{*}$ & $\rho=0,24^{\star *}$ \\
\hline Exposition to disengaged parenting style (Dis) & $\rho=-0,33^{\star *}$ & $\rho=-0,18^{*}$ & $\rho=-0,25^{\star}$ & $\rho=-0,26^{*}$ & $\rho=-0,33^{\star \star}$ \\
\hline
\end{tabular}

$\mathrm{N}=124 ; \mathrm{KS}$ p - significance of Kolmogorov - Smirnov normality test; r- Pearson correlation coefficient; $\rho$ - Spearman`s rank order correlation coefficient; *p<0,05; ** $\mathrm{p}<0,01$

As can be seen from data presented in Table 1, all values of Pearson correlation coefficient ( $\mathrm{r}$ ) between personality traits and general learning autonomy proved to be significant. The strongest positive relationship with general learning autonomy was observed in the case of conscientiousness $(\mathrm{r}=0,56$; $\mathrm{p}<0,01$ ), and the strongest negative relationship in the case of neuroticism $(r=-0,32 ; p<0,01)$.
To estimate the relationship between exposition to parenting styles and general learning autonomy, values of Spearman's rank order correlation coefficient $(\rho)$ were calculated. All obtained values of $\rho$ coefficient between exposition to parenting styles and general learning autonomy reached significance. A positive relationship was observed between general learning autonomy and exposition 
to democratic $(\rho=0,39 ; \mathrm{p}<0,01)$ and permissive parenting styles $(\rho=0,32 ; \quad p<0,01)$. A negative relationship was found between learning autonomy and exposition to disengaged $(\rho=-0,38 ; p<0,01)$ and authoritarian $(\rho=-0,33 ; p<0,01)$ parenting styles.

Correlation coefficients between personality traits, exposition to parenting styles and learning autonomy components were also analysed. The data are presented in Table 2. Self-control correlated significantly with only one personality trait: conscientiousness $(\mathrm{r}=0,59 ; \mathrm{p}<0,01)$. Reflexivity and care for the results proved to be related significantly to all personality traits from the Five-factor Model. In the case of reflexivity the strongest correlation was found with extraversion $(r=0,35 ; \mathrm{p}<0,01)$. Care for the results proved to have the strongest and negative relationship with neuroticism $(\mathrm{r}=-0,54$; $\mathrm{p}<0,01)$. Independence of planning was related significantly positively to conscientiousness $(\mathrm{r}=0,33$; $\mathrm{p}<0,01)$ and negatively, to neuroticism $(\mathrm{r}=-0,26$; $\mathrm{p}<0,01)$. Openness to change was found to correlate significantly with conscientiousness $(r=0,36 ; p<0,01)$ and agreeableness $(r=0,18 ; \mathrm{p}<0,05)$.

As values of rho correlation coefficient showed, all learning autonomy components analysed were related significantly and positively to exposition to democratic and permissive parenting styles and also significantly and negatively to exposition to autocratic and disengaged parenting styles.

\subsection{Selection and characteristics of the best model to predict general learning autonomy}

On the basis of correlation strength with learning autonomy three personality traits were selected for further analyses. Conscientiousness and openness to experiece were chosen because of their significant relationship with learning autonomy and lack of strong correlation with other personality traits. Neuroticism, despite it's significant correlation with conscientiousness and openness to experience was also selected. This was because out of the five analysed personality traits only conscientiousness had stronger relationship with learning autonomy than neuroticism. Extraversion and agreeableness were excluded from further analyses. Extraversion proved to have weaker relationship with general learning autonomy than with neuroticism, openness to experience and agreeableness. Agreeableness was found to be more strongly related to neuroticism, extraversion and conscientiousness, than to learning autonomy. The levels of exposition to all parenting styles proved to be strongly interrelated. Therefore, only exposition to democratic parenting style was chosen for further analyses because of the strength of its correlation with learning autonomy and normal distribution of its measurements.

Standard multiple regression models including general learning autonomy as dependent variable and all possible combinations of independent variables from the set containing: conscientiousness, neuroticism, openness to experience and exposition to democratic parenting style were compared to choose the model which allows for the best prediction of learning autonomy. The results are presented in Table 3. The lowest value of $\mathrm{Cp}$ statistics, indicating the model which best predicts general learning autonomy, was obtained when conscientiousness, openness to experience, and exposition to democratic parenting styles were taken as independent variables. The model was labeled as model I, and its parameters are presented in Tables 3 and 4 . The model as a whole reached significance $[F(3,120)=28,15 ; \quad p<0,01]$. It was found that conscientiousness, openness to experience and exposition to democratic parenting style explained $40 \%$ of the variance in general learning autonomy ( $\mathrm{R}$ Square $=0,41$; Adjusted $R$ Square $=0,40$ ). The value of the standard error of the estimate was 9,28. Values of standardized beta coefficients presented in Table 3 show, that out of three variables selected to the model conscientiousness is the strongest predictor of general learning autonomy (beta $=0,49$ ). Exposition to democratic parenting style (beta $=0,23$ ) and openness to experience (beta $=0,20$ ) proved to be much weaker contributors to general learning autonomy prediction. As can be deduced from the values of semipartial correlations shown in Table 4, conscientiousness uniquely explains $22 \%$ of the general learning autonomy variance (semipartial correlation 0,47 ), which is about half of the variance explained by the analyzed model. Exposition to democratic parenting style uniquely explains about $5 \%$ (semipartial correlation 0,22 ) and openness to experience $4 \%$ (semipartial correlation 0,20 ) of general learning autonomy variance.

A regression model predicting general learning autonomy including only consciousness and openness to experience as independent variables, labeled as model II, was also analysed. The data presented in Table 4 show that removing exposition to democratic parenting style from model 1 , which included both personality traits and exposition to democratic parenting style as independent variables, caused significant $5 \%$ decrease of the variance of learning autonomy explained.

\subsection{Selection and characteristics of the best model to predict learning autonomy components}

To select independent variables for regression models predicting learning autonomy components the strength of correlation between personality traits, exposition to parenting styles, and learning autonomy components shown in Table 2, was taken into account. Intercorrelations between personality 
Table 3. Comparison of regression models predicting general learning autonomy and its components

\begin{tabular}{|c|c|c|c|c|c|c|c|c|c|c|}
\hline \multirow{2}{*}{$\begin{array}{l}\text { Dependent } \\
\text { variable }\end{array}$} & \multirow{2}{*}{$\begin{array}{l}\text { Mo } \\
\text { del } \\
\text { no. }\end{array}$} & \multirow{2}{*}{$\begin{array}{c}\text { Num } \\
\text { ber } \\
\text { of } \\
\text { effects }\end{array}$} & \multirow{2}{*}{$\begin{array}{l}\text { Mal } \\
\text { low's - } \\
\text { Cp }\end{array}$} & \multirow{2}{*}{$\begin{array}{c}\text { Adjusted } \\
R \\
\text { - square }\end{array}$} & \multirow[b]{2}{*}{$\mathrm{F}$} & \multicolumn{5}{|c|}{ Independent variables; standardized regression coefficients (beta) } \\
\hline & & & & & & neuroticism & extraversion & $\begin{array}{l}\text { openness to } \\
\text { experience }\end{array}$ & $\begin{array}{l}\text { conscientio } \\
\text { usness }\end{array}$ & $\begin{array}{c}\text { exposition to } \\
\text { democratic } \\
\text { parenting style }\end{array}$ \\
\hline \multirow{10}{*}{$\begin{array}{c}\text { General } \\
\text { learning } \\
\text { autonomy }\end{array}$} & 1 & 3 & 4,084 & 0,398 & $F(3,120)=28,15 ; p<0,001$ & & $\mathrm{x}$ & $0,20^{* *}$ & $0,49^{\star \star \star}$ & $0,23^{\star *}$ \\
\hline & 2 & 4 & 5,000 & 0,399 & $F(4,119)=21,40 ; p<0,001$ & $-0,08$ & $\mathrm{x}$ & $0,17^{*}$ & $0,48^{* \star *}$ & $0,22^{\star \star}$ \\
\hline & 3 & 3 & 8,204 & 0,378 & $F(3,120)=25,89 ; p<0,001$ & $-0,15$ & $\mathrm{x}$ & & $0,46^{\star \star \star}$ & $0,23^{\star \star}$ \\
\hline & 4 & 2 & 10,095 & 0,364 & $F(2,121)=36,13 ; p<0,001$ & & $\mathrm{x}$ & & $0,49^{\star \star *}$ & $0,26^{\star \star \star}$ \\
\hline & 5 & 3 & 11,700 & 0,360 & $F(3,120)=24,09 ; p<0,001$ & $-0,12$ & $\mathrm{x}$ & $0,19^{*}$ & $0,53^{\star \star \star}$ & \\
\hline & 6 & 2 & 11,944 & 0,354 & $F(2,121)=34,76 ; p<0,001$ & & $\mathrm{x}$ & $0,23^{* *}$ & $0,56^{\star \star *}$ & \\
\hline & 7 & 2 & 15,800 & 0,335 & $F(2,121)=32,40 ; p<0,001$ & $-0,19^{*}$ & $\mathrm{x}$ & & $0,51^{\star \star *}$ & \\
\hline & 8 & 1 & 20,481 & 0,308 & $F(1 ; 122)=55,68 ; p<0,001$ & & $\mathrm{x}$ & & $0,56^{\star \star *}$ & \\
\hline & 9 & 3 & 43,268 & 0,202 & $F(3,120)=11,38 ; p<0,001$ & $-0,20^{*}$ & $\mathrm{x}$ & 0,124 & & $0,33^{* * *}$ \\
\hline & 10 & 2 & 44,008 & 0,195 & $F(2,121)=15,91 ; p<0,001$ & $-0,24^{\star *}$ & $\mathrm{x}$ & & & $0,33^{\star \star *}$ \\
\hline \multirow[t]{3}{*}{ Self-control } & 1 & 2 & 3,00 & 0,38 & $F(2,121)=38,07 ; p<0,001$ & $\mathrm{x}$ & $\mathrm{x}$ & $\mathrm{x}$ & $0,52^{* \star *}$ & $0,23^{* *}$ \\
\hline & 2 & 1 & 10,60 & 0,33 & $F(1,122)=62,75 ; p<0,001$ & $\mathrm{x}$ & $\mathrm{x}$ & $\mathrm{x}$ & & $0,59^{\star \star \star}$ \\
\hline & 3 & 1 & 50,94 & 0,13 & $F(1,122)=19,66 ; p<0,001$ & $\mathrm{x}$ & $\mathrm{x}$ & $\mathrm{x}$ & $0,37^{\star \star *}$ & \\
\hline \multirow[t]{10}{*}{ Reflexivity } & 1 & 3 & 3,96 & 0,16 & $F(3,120)=8,95 ; p<0,001$ & $\mathrm{x}$ & $0,25^{\star \star}$ & $0,18^{*}$ & $0,19^{*}$ & \\
\hline & 2 & 4 & 5,00 & 0,16 & $F(4,119)=6,78 ; p<0,001$ & $\mathrm{x}$ & $0,24^{\star *}$ & 0,17 & 0,17 & 0,08 \\
\hline & 3 & 2 & 6,04 & 0,14 & $F(2,121)=11,20 ; p<0,001$ & $\mathrm{x}$ & $0,31^{\star * *}$ & & $0,18^{*}$ & \\
\hline & 4 & 3 & 6,74 & 0,14 & $F(3,120)=7,69 ; p<0,001$ & $\mathrm{x}$ & $0,27^{\star \star}$ & 0,16 & & 0,13 \\
\hline & 5 & 3 & 6,75 & 0,14 & $F(3,120)=7,67 ; p<0,001$ & $\mathrm{x}$ & $0,30^{\star \star *}$ & & 0,16 & 0,10 \\
\hline & 6 & 2 & 7,08 & 0,13 & $F(2,121)=10,62 ; p<0,001$ & $\mathrm{x}$ & $0,29^{* * *}$ & 0,17 & & \\
\hline & 7 & 2 & 8,03 & 0,13 & $F(2,121)=9,86 ; p<0,001$ & $\mathrm{x}$ & $0,32^{\star \star \star}$ & & & 0,14 \\
\hline & 8 & 1 & 8,75 & 0,11 & $F(1,122)=17,64 ; p<0,001$ & $x$ & $0,35^{\star \star \star}$ & & & \\
\hline & 9 & 2 & 10,00 & 0,11 & $F(2,121)=8,91 ; p<0,001$ & $\mathrm{x}$ & & $0,26^{* *}$ & $0,23^{\star *}$ & \\
\hline & 10 & 3 & 10,31 & 0,11 & $F(3,120)=6,29 ; p<0,001$ & $x$ & & $0,25^{\star *}$ & $0,20^{*}$ & 0,11 \\
\hline \multirow{7}{*}{$\begin{array}{c}\text { Indepen } \\
\text { dence } \\
\text { of } \\
\text { planning }\end{array}$} & 1 & 2 & 2,88 & 0,13 & $F(2,121)=10,01 ; p<0,001$ & $-0,19$ & $\mathrm{X}$ & $\mathrm{X}$ & $0,29^{\star \star \star}$ & \\
\hline & 2 & 3 & 4,00 & 0,13 & $F(3,120)=7,24 ; p<0,001$ & $-0,17$ & $x$ & $x$ & $0,27^{\star \star}$ & 0,08 \\
\hline & 3 & 1 & 5,37 & 0,11 & $F(1,122)=16,41 ; p<0,001$ & & $\mathrm{x}$ & $\mathrm{X}$ & $0,34^{* \star *}$ & \\
\hline & 4 & 2 & 5,65 & 0,11 & $F(2,121)=9,01 ; p<0,001$ & & $\mathrm{x}$ & $\mathrm{X}$ & $0,30^{* \star \star}$ & 0,11 \\
\hline & 5 & 2 & 10,89 & 0,07 & $F(2,121)=5,71 ; p<0,004$ & $-0,23^{*}$ & $\mathrm{X}$ & $x$ & & 0,14 \\
\hline & 6 & 1 & 11,67 & 0,06 & $F(1,122)=7,31 ; p<0,008$ & $-0,26^{\star *}$ & $x$ & $x$ & & \\
\hline & 7 & 1 & 15,64 & 0,03 & $F(1,122)=5,09 ; p<0,026$ & & $\mathrm{x}$ & $x$ & & $0,20^{*}$ \\
\hline \multirow{3}{*}{$\begin{array}{c}\text { Openness } \\
\text { to } \\
\text { change }\end{array}$} & 1 & 2 & 3,00 & 0,14 & $F(2,121)=11,33 ; p<0,001$ & $\mathrm{x}$ & $x$ & $x$ & $0,31^{\star \star \star}$ & $0,18^{*}$ \\
\hline & 2 & 1 & 5,22 & 0,12 & $F(1,122)=18,15 ; p<0,001$ & $x$ & $x$ & $x$ & $0,36^{\star \star \star}$ & \\
\hline & 3 & 1 & 13,58 & 0,06 & $F(1,122)=16,41 ; p<0,001$ & $x$ & $x$ & $x$ & & $0,26^{\star \star}$ \\
\hline \multirow{10}{*}{$\begin{array}{l}\text { Care } \\
\text { for } \\
\text { the results }\end{array}$} & 1 & 4 & 5,00 & 0,45 & $F(4,119)=26,52 ; p<0,001$ & $-0,34^{\star * \star}$ & $x$ & $0,22^{* *}$ & $0,31^{* \star *}$ & 0,17 * \\
\hline & 2 & 3 & 8,55 & 0,43 & $F(2,121)=32,10 ; p<0,001$ & $-0,37^{\star \star *}$ & $x$ & $0,23^{\star *}$ & $0,35^{\star \star *}$ & \\
\hline & 3 & 3 & 12,15 & 0,41 & $F(3,120)=29,92 ; p<0,001$ & $-0,42^{\star * \star}$ & $x$ & & $0,29^{* \star *}$ & $0,18^{*}$ \\
\hline & 4 & 2 & 16,65 & 0,39 & $F(2,121)=40,43 ; p<0,001$ & $-0,46^{\star * \star}$ & $x$ & & $0,33^{\star * *}$ & \\
\hline & 5 & 3 & 21,88 & 0,37 & $F(3,120)=24,64 ; p<0,001$ & $-0,42^{\star \star \star}$ & $x$ & $1,19^{*}$ & & $0,24^{\star *}$ \\
\hline & 6 & 3 & 23,55 & 0,36 & $F(3,120)=25,00 ; p<0,001$ & & $x$ & $0,33^{\star * *}$ & $0,39^{\star \star \star}$ & $0,22^{\star \star}$ \\
\hline & 7 & 2 & 26,65 & 0,34 & $F(2,121)=32,53 ; p<0,001$ & $-0,48^{* * *}$ & $x$ & & & $0,25^{\star \star \star}$ \\
\hline & 8 & 2 & 30,96 & 0,32 & $F(2,121)=31,94 ; p<0,001$ & & $x$ & $0,36^{* \star *}$ & $0,45^{\star \star \star}$ & \\
\hline & 9 & 2 & 31,88 & 0,32 & $F(2,121)=28,81 ; p<0,001$ & $-0,47^{* \star *}$ & $x$ & $0,20^{*}$ & & \\
\hline & 10 & 1 & 37,42 & 0,29 & $F(1,122)=50,20 ; p<0,001$ & $-0,54^{\star \star \star}$ & $\mathrm{x}$ & & & \\
\hline
\end{tabular}

$\mathrm{N}=124 ; * \mathrm{p}<0,05, * * \mathrm{p}<0,01 ; * * * \mathrm{p}<0,001 ; \mathrm{X}$-variable excluded from analyses

traits and four kinds of analysed parenting styles presented in Table 1 were also considered.

For all learning autonomy components exposition to democratic parenting style was chosen as independent variable. Exposition to one kind of parenting style was selected because of high intercorrelations between analysed kinds of parental influences. Exposition to democratic parenting style was chosen because of normal distribution of its measurements and the highest strength of the relationship between exposition to this parenting style and all learning autonomy components with the exception of independence of planning. The set of parental influences to which independence of planning proved to be related most strongly was exposition to autocratic parenting style $(\mathrm{rho}=-0,25$; $\mathrm{p}<0,05$ ). However, the relative value of correlation coefficient between independence of planning and exposition to democratic parenting style (rho $=0,23$; $\mathrm{p}<0,05)$ indicated almost the same strength of relationship, therefore also in the case of 
Table 4. Comparison of learning autonomy variance explained by personality traits and exposition to democratic parenting style

\begin{tabular}{|c|c|c|c|c|c|c|c|c|c|c|c|c|}
\hline Model & $\begin{array}{l}\text { Independent } \\
\text { variables }\end{array}$ & $\begin{array}{c}\text { B } \\
\text { unstandardized } \\
\text { coefficient }\end{array}$ & B 95\% Cl & $t(120)$ & $\begin{array}{c}\text { Partial } \\
\text { correlation }\end{array}$ & $\begin{array}{l}\text { Semipartial } \\
\text { correlation }\end{array}$ & $\begin{array}{l}\text { Tole } \\
\text { rance }\end{array}$ & $\begin{array}{l}\text { KS p } \\
\text { for } \\
\text { residu } \\
\text { als }\end{array}$ & $\begin{array}{c}\text { Durbin - } \\
\text { Watson } \\
\text { statistics; } \\
\text { p }\end{array}$ & $\mathrm{F}$ & $\mathrm{R}^{2}$ & $\Delta \mathrm{R}^{2}$ \\
\hline \multirow{4}{*}{ Model I } & Constant & 31,48 & $18,49-44,47$ & $4,80^{* *}$ & & & & \multirow{4}{*}{$p>0,20$} & \multirow{4}{*}{$2,15, \mathrm{~ns}$} & \multirow{4}{*}{$28,15^{\star *}$} & \multirow{4}{*}{0,41} & \multirow{7}{*}{$0,05^{\star \star}$} \\
\hline & $\begin{array}{c}\text { Conscientiousn } \\
\text { ess }\end{array}$ & 1,02 & $0,72-1,31$ & $6,77^{\star *}$ & 0,53 & 0,47 & 0,92 & & & & & \\
\hline & Openness & 0,41 & $0,12-0,69$ & $2,83^{\star *}$ & 0,25 & 0,20 & 0,98 & & & & & \\
\hline & $\begin{array}{c}\text { Exposition to } \\
\text { democratic } \\
\text { parenting style }\end{array}$ & 0,45 & $0,17-0,73$ & $3,14^{\star *}$ & 0,28 & 0,22 & 0,91 & & & & & \\
\hline \multirow{3}{*}{ Model II } & Constant & 39,74 & $27,4-52,06$ & $6,38^{* *}$ & & & & \multirow{3}{*}{$p>0,20$} & \multirow{3}{*}{2,$04 ;$ ns } & \multirow{3}{*}{$34,76^{\star *}$} & \multirow{3}{*}{0,37} & \\
\hline & $\begin{array}{c}\text { Conscientiousn } \\
\text { ess } \\
\end{array}$ & 1,15 & $0,85-1,44$ & $7,68^{\star *}$ & 0,57 & 0,56 & 1,00 & & & & & \\
\hline & Openness & 0,46 & $0,17-0,76$ & $3,13^{\star \star}$ & 0,27 & 0,23 & 1,00 & & & & & \\
\hline
\end{tabular}

$* \mathrm{p}<0,05 ; * * \mathrm{p}<0,01$

independence of planning exposition to democratic parenting style was selected as independent variable.

For regression models predicting self-control conscientiousness was chosen as independent variable because it proved to be the only personality trait significantly related to this learning autonomy component.

In the case of reflexivity, despite significant correlations with all five analysed personality traits, three were selected as independent variables: extraversion, conscientiousness and openness to experience. Neuroticism and agreeableness were excluded because of higher correlation coefficients with extraversion $(\mathrm{r}=-0,58 ; \mathrm{p}<0,01$ and $\mathrm{r}=0,34$; $\mathrm{p}<0,01$, respectively) than with reflexivity $(\mathrm{r}=-0,28$; $\mathrm{p}<0,01$ and $\mathrm{r}=0,18 ; \mathrm{p}<0,05$, respectively).

It was decided that neuroticism and conscientiousness would be included in the set of independent variables predicting independence of planning as the only personality traits significantly related to this learning autonomy component.

Conscientiousness was selected as independent variable for regression models describing openness to change out of two personality traits significantly related to the measurements of this Learning Autonomy Inventory scale. Agreeableness was excluded from further analyses because its relationship to openness to change $(r=0,18 ; p<0,05)$, although significant, was weaker than with conscientiousness $(r=0,26 ; p<0,01)$.

Out of five personality traits significantly related to care for the results three were chosen as independent variables for regression models: neuroticism, conscientiousness and openness to experience. Extraversion was excluded because of its higher correlation with neuroticism $(\mathrm{r}=-0,58 ; \mathrm{p}<0,01)$ than with care for the results $(r=0,42 ; p<0,01)$. Agreeableness proved to have higher values of correlation coefficient with neuroticism $(\mathrm{r}=-0,34$; $\mathrm{p}<0,01)$ and conscientiousness $(\mathrm{r}=0,26<0,01)$ than with care for the results $(r=0,20 ; p<0,05)$.

After selecting independent variables, various regression models predicting each learning autonomy component were compared by means of Mallow`s $\mathrm{Cp}$ statistics. The results of this comparison are presented in Table 3. Table 5 shows detailed characteristics of parameters describing the best regression model for each learning autonomy component.

The best predictive model for self-control included conscientiousness (beta $=0,52 ; \mathrm{p}<0,001$ ) and exposition to democratic parenting style (beta $=0,23$; $\mathrm{p}<0,01)$ and proved to explain $38 \%$ of self - control variance $[\mathrm{F}(2,121)=38,07 ; \mathrm{p}<0,001]$. Values of semipartial correlation presented in Table 5 show that 25 percent of self-control variance was

Table 5. Parameters of the best models predicting learning autonomy components

\begin{tabular}{|c|c|c|c|c|c|c|c|c|c|c|}
\hline $\begin{array}{l}\text { Dependent } \\
\text { variable }\end{array}$ & Independent variables & B & $\begin{array}{c}\mathrm{B} \\
95 \% \mathrm{Cl}\end{array}$ & $\begin{array}{c}\text { Partial } \\
\text { correlati } \\
\text { on }\end{array}$ & $\begin{array}{l}\text { Semi-partial } \\
\text { correlation }\end{array}$ & $\mathrm{t}$ & $\mathrm{p}$ & $\begin{array}{l}\text { Tole } \\
\text { rance }\end{array}$ & $\begin{array}{c}\text { KS p } \\
\text { for } \\
\text { residuals }\end{array}$ & $\begin{array}{c}\text { Durbin } \\
\text { Watson } \\
\text { statistics; } p\end{array}$ \\
\hline \multirow{3}{*}{$\begin{array}{l}\text { Self- } \\
\text { control }\end{array}$} & constant & 3,81 & $-0,72-8,33$ & & & 1,67 & 0,100 & & \multirow{3}{*}{$p<0,15$} & \multirow{3}{*}{2,$22 ; n s$} \\
\hline & conscientiousness & 0,43 & $0,31-0,55$ & 0,54 & 0,50 & 6,98 & 0,001 & 0,92 & & \\
\hline & $\begin{array}{l}\text { exposition to } \\
\text { democratic parenting style }\end{array}$ & 0,18 & $0,06-0,29$ & 0,27 & 0,22 & 3,09 & 0,002 & 0,92 & & \\
\hline \multirow[t]{4}{*}{ Reflexivity } & constant & 9,33 & $5,96-12,70$ & & & 5,48 & 0,001 & & \multirow{4}{*}{$p>0,20$} & \multirow{4}{*}{1,$90 ; \mathrm{ns}$} \\
\hline & extraversion & 0,11 & $0,03-0,19$ & 0,25 & 0,23 & 2,83 & 0,005 & 0,83 & & \\
\hline & conscientiousness & 0,09 & $0,01-0,17$ & 0,20 & 0,18 & 2,20 & 0,028 & 0,96 & & \\
\hline & openness & 0,08 & $0,00-0,16$ & 0,18 & 0,16 & 1,98 & 0,050 & 0,86 & & \\
\hline \multirow{3}{*}{$\begin{array}{l}\text { Indepen } \\
\text { dence } \\
\text { of planning }\end{array}$} & constant & 13,75 & $10,28-17,22$ & & & 7,84 & 0,001 & & \multirow{3}{*}{$p>0,20$} & \multirow{3}{*}{1,$97 ; \mathrm{ns}$} \\
\hline & conscientiousness & 0,15 & $0,07-0,24$ & 0,30 & 0,29 & 3,47 & 0,001 & 0,93 & & \\
\hline & neuroticism & $-0,06$ & $-0,12-0,05$ & $-0,16$ & 0,15 & 1,82 & 0,070 & 0,93 & & \\
\hline \multirow{3}{*}{$\begin{array}{l}\text { Openness } \\
\text { to change }\end{array}$} & constant & 5,94 & $3,26-8,61$ & & & 4,40 & 0,001 & & \multirow{3}{*}{$p>0,20$} & \multirow{3}{*}{1,$96 ; \mathrm{ns}$} \\
\hline & conscientiousness & 0,13 & $0,06-0,20$ & 0,31 & 0,30 & 3,56 & 0,001 & 0,92 & & \\
\hline & $\begin{array}{l}\text { exposition to } \\
\text { democratic parenting style }\end{array}$ & 0,07 & $0,00-0,14$ & 0,18 & 0,17 & 2,04 & 0,043 & 0,92 & & \\
\hline \multirow{5}{*}{$\begin{array}{l}\text { Care for } \\
\text { the results }\end{array}$} & constant & 9,93 & $5,56-14,43$ & & & 4,46 & 0,001 & & \multirow{5}{*}{$p>0,20$} & \multirow{5}{*}{1,$98 ; \mathrm{ns}$} \\
\hline & neuroticism & $-0,13$ & $-0,19-0,07$ & $-0,38$ & $-0,30$ & 4,41 & 0,001 & 0,78 & & \\
\hline & conscientiousness & 0,18 & $0,10-0,25$ & 0,38 & 0,30 & 4,50 & 0,001 & 0,87 & & \\
\hline & openness & 0,12 & $0,04-0,20$ & 0,28 & 0,21 & 3,12 & 0,002 & 0,86 & & \\
\hline & $\begin{array}{l}\text { exposition to } \\
\text { Democratic parenting style }\end{array}$ & 0,09 & $0,01-0,16$ & 0,21 & 0,16 & 2,36 & 0,020 & 0,89 & & \\
\hline
\end{tabular}


explained by conscientiousness (value of semipartial correltation 0,50 ), whereas only $5 \%$ by exposition to democratic parenting style (semipartial correltation $0,22)$.

Reflexivity was found to be best predicted by extraversion (beta $=0,25 ; \mathrm{p}<0,01$ ), conscientiousness (beta $=0,19 ; \mathrm{p}<0,05$ ) and openness to experience (beta $=0,18 ; \mathrm{p}<0,05$ ). The three personality traits explained $16 \%$ of reflexivity variance $[\mathrm{F}(3,120)=8,95 ; \mathrm{p}<0,001]$.

Regression model which proved to be the best in predicting independence of planning explained $13 \%$ of this learning autonomy component variance $[\mathrm{F}(2,121)=10,01 ; \quad \mathrm{p}<0,001]$ and consisted of conscientiousness (beta $=0,29 ; \quad \mathrm{p}<0,001)$ and neuroticism (beta $=-0,19 ; \mathrm{p}=0,07)$.

Openness to change was found to be best predicted by conscientiousness (beta $=0,31 ; \mathrm{p}<0,001$ ) and exposition to democratic parenting style (beta $=0,18 ; \mathrm{p}<0,05)$. The model proved to be significant $[\mathrm{F}(2,120)=11,33 ; \mathrm{p}<0,001]$ and explain $14 \%$ of openness to change variance. As can be calculated from values of semipartial correlations shown in Table 5, conscientiousness uniquely explains $9 \%$ of openness to change variance (semipartial correlation 0,30 ) whereas exposition to democratic parenting style only $3 \%$.

The best predictive regression model for care for the results explained $45 \%$ of this learning autonomy component variance $[\mathrm{F}(4,118)=26,52 ; \mathrm{p}<0,001]$. The model included four following independent variables: neuroticism (beta $=-0,34 ; \mathrm{p}<0,001$ ), conscientiousness (beta $=0,31 ; p<0,001$ ), openness to experience (beta $=0,22 ; \mathrm{p}<0,01$ ) and exposition to democratic parenting style (beta $=0,17 ; \mathrm{p}<0,05$ ). Based on the values of semipartial correlations presented in Table 5 it can be calculated that, the largest proportion of care for the results variance was explained by neuroticism (9\%) and conscientiousness $(9 \%)$. Openness to experience and exposition to democratic parenting style proved to explain $4 \%$ and $2 \%$ of care for the results, respectively.

\subsection{Generalizability of the best predictive models of learning autonomy and its components.}

After estimation of best predictive models for learning autonomy and its components analyses were performed to check whether assumptions of multiple regression method were not violated. Especially statistics concerning normality of residuals, correlations between independent variables and correlations of residuals for the analysed best predictive models were calculated. Tables 4 and 5 present values of Kolmogorov - Smirnov normality test of residuals as well as values of Tolerance and
Durbin - Watson test. Both in the case of Models I and II concerning general learning autonomy presented in Table 4, and in the case of best predictive models for learning autonomy components shown in Table 5, no serious deviations from regression method assumptions were observed. Values of Kolmogorov-Smirnov test were not significant, values of Tolerance were higher than 0,2 and Durbin - Watson statistics did not indicate significant correlation between residuals. This means that multiple regression results concerning best predictive models for learning autonomy and its five analyzed components can be generalized.

\section{Discussion}

The aim of the research was to answer the question: to what extent is the level of general learning autonomy and its components related to personality traits and to what extent to influences characteristic to parenting styles? One hundred and four Polish students completed NEO-FFI, Parenting Styles in a Family Questionnaire and Learning Autonomy Inventory.

Given that the majority of the data were gathered from female participants the results can mainly be generalized to women.

All possible standard regression models including neuroticism, conscientiousness, openness and exposition to democratic parenting style were compared in terms of their strength to predict general learning autonomy by means of Mallow's Cp statistics value.

The results showed that the model which allows for the best prediction of general learning autonomy includes conscientiousness, openness to experience, and exposition to democratic parenting style as independent variables. It was also found that conscientiousness is the strongest predictor of learning autonomy. These results are consistent with the results of B. Hmel and A. Pincus [3] who also found positive relationship between conscientiousness and autonomy conceptualized as governing oneself.

The comparison of general learning autonomy variance explained by conscientiousness, openness to experience and exposition to democratic parenting style $(41 \%)$ with learning autonomy variance related only to conscientiousness and openness to experience $(37 \%)$ revealed, that exposition to democratic parenting style during adolescence contributes significantly to the level of learning autonomy in young adults. L. Steinberg, J. Elmen, and N. Mounts [20] as well as B. Soenens and M. Vansteenkiste [7] also found positive relationship between democratic and authoritative parenting styles and autonomy of the child. 
Analysis of the best 33 predictive models for general learning autonomy components indicates three major findings. Firstly, conscientiousness proved to be a significant predictor of all five analysed learning autonomy components. Secondly, exposition to democratic parenting style contributed significantly to the prediction of three out of five analysed learning autonomy components: selfcontrol, openness to change and care for the results. No significant contribution of democratic parental influences to the prediction of reflexivity and independence of planning was found. Finally, personality traits and exposition to parenting styles explained about $40 \%$ of the variance of such learning autonomy components as self-control and care for the results. In the case of reflexivity, independence of planning and openness to change, the amount of variance explained by the traits from Five Factor Model and democratic parental influences did not exceed $20 \%$.

\section{Conclusions}

Based on study results it may be concluded, that in women:

- Level of general learning autonomy and its components can be better predicted by personality traits which are partly genetically inherited than by parental environment.

- Out of personality traits from Five-Factor Model conscientiousness is the one which is significantly related to all analysed general autonomy components: self-control, reflexivity, independence of planning, openness to change and care for the results.

- Environmental influences in the form of democratic parenting style contribute significantly to the prediction of such learning autonomy components as self-control, openness to change and care for the results.

- The study results should be confirmed on the group of participants including larger proportion of men and students from various educational levels.

- Further studies could focus on finding better predictors for reflexivity, independence of planning and openness to change than personality traits and parental influences.

- Fostering learning autonomy should be aimed at enhancing conscientiousness in the environment where decisions concerned with learning are shared between adolescents and their educators.

\section{References}

[1] Haworth, L., Autonomy. An Essay in Philosophical Psychology and Ethics, Yale University Press, New Haven and London, 1986, p.42.

[2] D. Fazey, J. Fazey, "The Potential for Autonomy in Learning: Perceptions of Competence, Motivation and Locus of Control in First-year Undergraduate Students", Studies in Higher Education, 2001, 26 (3), pp. 345-362.

[3] B. A. Hmel, A. L Pincus, "The Meaning of Autonomy: on and beyond the Interpersonal Circumplex", Journal of Personality, 2002, 70 (3), pp. 277-309.

[4] C. W. Langfred, "Autonomy and Performance in Teams: the Multilevel Moderating Effect of Task Independence", Journal of Management, 2005, 31, pp. 513-529.

[5] R. M. Ryan, E. L. Deci, "Self-regulation and the Problem of Human Autonomy: Does Psychology Need Choice, Self-determination and Will?", Journal of Personality, 2006, 74 (6), pp. 1557-1585.

[6] M. Noom, "Theoretical Perspectives on Adolescent Autonomy". In: Noom M., Adolescent Autonomy: Characteristics and Correlates, Eburon Publishers, Delft, 1999, pp.5-21.

[7] B. Soenens, M. Vansteenkiste, "Antecendants and Outcomes of Self- determination in 3 Life Domains: the Role of Parents' and Teachers' Autonomy Support", Journal of Youth and Adolescence, 2005, 34 (6), pp. 589604.

[8] A. Studenska, "Personality Traits, Exposition to Parenting Styles and Learning Autonomy". In: Shoniregun Ch., Akmayeva G. Ireland International Conference on Education Proceedings 2011, ISBN 978-1-908320-02-5, pp. $165-170$.

[9] R. Koestner, G. Losier, "Distinguishing Reactive Versus Reflective Autonomy", Journal of Personality, 1996, 64 (2), pp.465-494.

[10] Dworkin, G., The Theory and Practice of Autonomy, Cambridge University Press, Cambridge, 1988.

[11] Mele, A. R., Autonomous Agents. From Self-control to Autonomy, Oxford University Press, Oxford, 2001.

[12] Benson, P., Teaching and Researching Autonomy in Language Learning, Pearson Education Limited, London, 2001, p. 47.

[13] M. Ponton, P. Carr, "Understanding and Promoting Autonomy in Self-directed Learning". Current Research in Social Psychology, 2000, 5(19), pp. 271-284.

[14] B. Zimmerman, "Becoming a Self-regulated Learner: an Overview". Theory Into Practice, 2002, 41(2), pp. 6470 . 
[15] McCrae, R., P. T Costa, Personality in Adulthood. A Five-factor Theory Perspective, Guliford Press, New York, 2002.

[16] D. Baumrind, "Effects of Authoritative Control on Child`s Behavior", Child Development, 1966, 37 (4), pp. $887-907$.

[17] D. Baumrind, "Patterns of Parental Authority and Adolescent Autonomy", New Directions for Child and Adolescent Development , 2005, 108, pp. 61-69.

[18] E. Mansager, R. Volk, "Parent's Prism: Three Dimensions of Effective Parenting", Journal of Individual Psychology, 2004, 60 (3), pp. $277-293$.

[19] E. Skinner, S. Johnson, and T. Snyder, "Six Dimensions of Parenting: a Motivational Model", Parenting: Science and Practice, 2005, 5(2), pp. 175-235.

[20] L. Steinberg, J. D. Elmen, and N. S. Mounts, "Authoritative Parenting, Psychosocial Maturity and Academic Success among Adolescents", Child Development, 1989, 60, pp. 1424-1436.

[21] J. Walker, "Looking at Teacher Practices through the Lens of Parenting Style". The Journal of Experimental Education, 2008, 76(2), pp. 218 -240.

[22] W. Grolnick, N. Apostoleris, , "What Makes parents controlling?” In: Deci, E., R. Ryan, Handbook of Self determination Research, The University of Rochester Press, Rochester, 2002, pp. 161-181.

[23] M. Joussemet, R. Koestner, N. Lekes, and R. Landry, "A Longitudinal Study of the Relationship of Maternal Autonomy Support to Children's Adjustment and Achievement at School", Journal of Personality, 2005, 75 (5), pp. 1215-1235.

[24] Zawadzki, B., J. Strelau, P. Szczepaniak, and M. Śliwińska, Inwentarz Osobowości NEO-FFI Costy $i$ McCrae, Pracownia Testów Psychologicznych Polskiego Towarzystwa Psychologicznego, Warszawa, 1988.

[25] Ryś, M., Systemy rodzinne: Metody badań struktury rodziny pochodzenia $i$ rodziny własnej, CMPPP, Warszawa, 2004.

[26] Studenska, A. Inwentarz Autonomii Uczenia się (IAU) Podręcznik, CMPPP, Warszawa, 2009.

[27] Hill, T., Lewicki, P. Statistics: Methods and Applications. StatSoft Inc, Tulsa, 2006. 